\title{
Autologous TCR-engineered T-cells IMA202
}

National Cancer Institute

\section{Source}

National Cancer Institute. Autologous TCR-engineered T-cells IMA202. NCI Thesaurus.

Code C153218.

A preparation of autologous T-lymphocytes that are genetically modified with a lentiviral vector encoding a T-cell receptor (TCR) targeting patient-specific tumor associated antigens (TAAs), with potential antineoplastic activity. Upon intravenous administration back into the patient, the autologous TCR-engineered T-cells IMA202 specifically recognize and bind to the TAA on cancer cells, which induces a cytotoxic T-lymphocyte (CTL)-mediated immune response against the TAA-positive cancer cells. 